\title{
Program Kemitraan Masyarakat: Perancangan Praktikum Matematika dan IPA Sederhana bagi Guru SMP
}

\author{
Community Partnership Program: Designing Simple Mathematics and Science Practicum for \\ Junior High School Teachers
}

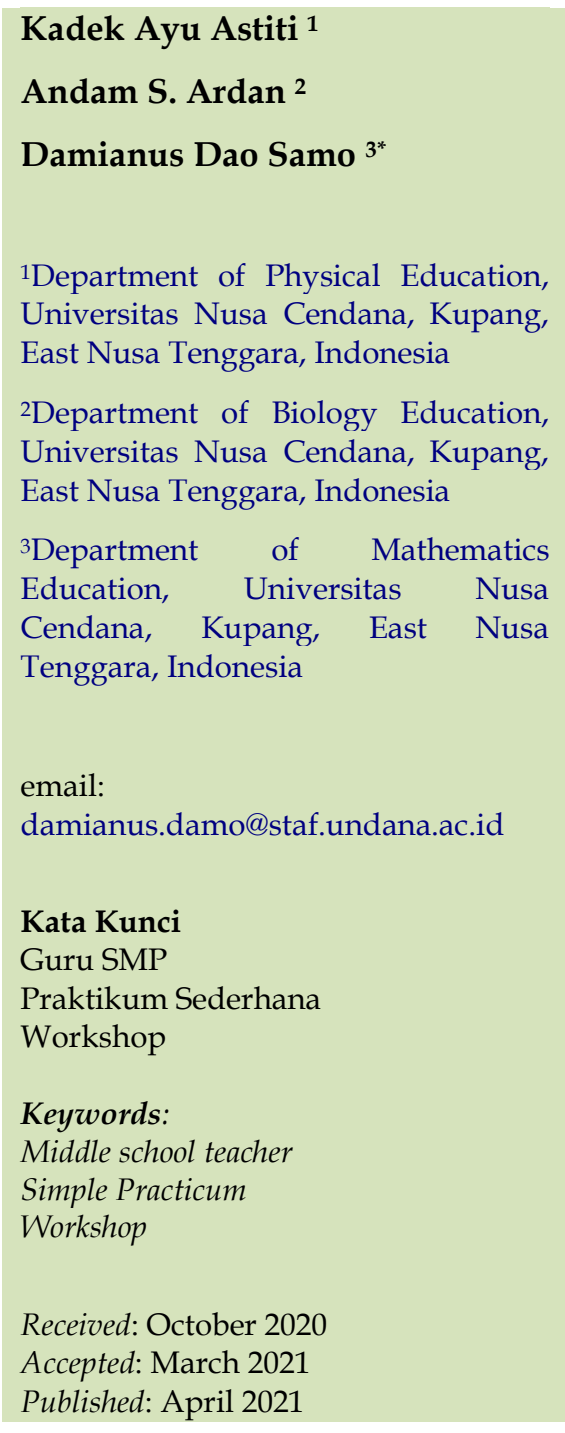

\begin{abstract}
Abstrak
Kegiatan pengabdian kepada masyarakat ini bertujuan untuk meningkatan keterampilan guru dalam melaksanakan kegiatan praktikum MIPA sederhana. Kegiatan ini dirancang dalam bentuk pelatihan yang melalui beberapa tahapan yakni 1) berkoordinasi dengan sekolah mitra untuk waktu pelaksanaan, 2) pemberian materi terkait praktikum matematika dan IPA sederhana, 3) Pendampingan kepada guru-guru MIPA dalam merancang praktikum sederhana, dan 4) evaluasi program. Peserta kegiatan ini adalah beberapa guru MIPA yang berasal dari SMP N 1 Nekamese, SMP N 2 Nekamese, SMP N 4 Nekamese, dan SMP N 5 Nekamese. Dalam kegiatan pelatihan, peserta cukup antusias dalam mengikuti kegiatan yang terlihat dari semangat untuk datang mengikuti kegiatan, serta diskusi yang dinamis. Berdasarkan hasil tes akhir terdapat peningkatan kemampuan guru sebelum dan setelah pelatihan dengan nilai n-gain dalam kategori tinggi.
\end{abstract}

\begin{abstract}
This community service activity improves teacher skills in carrying out simple Mathematics and Natural Sciences practical activities. This activity is designed in the form of training through several stages, namely 1) coordinating with partner schools for implementation time, 2) providing material related to simple mathematics and science practicum, 3) Mentoring for Mathematics and Natural Sciences teachers in designing simple practicums, and 4) program evaluation. Participants in this activity were several Mathematics and Natural Sciences teachers from SMP N 1 Nekamese, SMP N 2 Nekamese, SMP N 4 Nekamese, and SMP N 5 Nekamese. In the training activities, the participants were quite enthusiastic in participating in the activities, which could be seen from the enthusiasm to participate in the activities and dynamic discussions. Based on the final test results, there was an increase in the teacher's ability before and after the training with an n-gain value in the high category.
\end{abstract}

(C) 2021 Kadek Ayu Astiti, Andam S Ardan, Damianus Dao Samo. Published by Institute for Research and Community Services Universitas Muhammadiyah Palangkaraya. This is Open Access article under the CC-BYSA License (http://creativecommons.org/licenses/by-sa/4.0/).

DOI: https://doi.org/10.33084/pengabdianmu.v6i3.1787

\section{PENDAHULUAN}

Mata pelajaran matematika dan IPA merupakan mata pelajaran esensial yang diajarkan di sekolah menengah. Tujuan mata pelajaran ini adalah untuk membentuk keterampilan proses dan keterampilan berpikir siswa yang dapat diimplementasikan dalam hidupnya terkait pemecahan masalah. Sebagai mata pelajaran esensial, pembelajaran matematika dan IPA di kelas harus difasilitasi dengan media-media pembelajaran yang dapat membantu siswa memahami materi dan memecahkan masalah (Sulthon, 2016; Sumartini, 2016). 
Menurut Samura (2015), media pembelajaran berfungsi sebagai fungsi atensi, fungsi afektif, fungsi kognitif, dan fungsi kompensatoris dan juga bermanfaat sebagai memperlancar interaksi antara guru dengan siswa sehingga pembelajaran akan lebih efektif dan efisien. Selain media pembelajaran, kegiatan pembelajaran harus dijuga difasilitasi dengan kegiatan praktikum sederhana sebagai bagian dari pembentukan retensi informasi jangka panjang dari siswa. Kegiatan ini menjadi terkendala bagi sekolah khususnya guru karena berbagai keterbatasan ketersediaan media/alat praktikum/percobaan sederhana tersebut (Rahman et al., 2015).

Ketersediaan alat dan bahan yang terbatas membuat guru jarang melaksanakan kegiatan praktikum, namun selain itu guru-guru enggan melaksanakan praktikum karena menurut mereka praktikum membutuhkan waktu yang banyak apalagi praktikum fisika dan kimia yang perlu waktu lama untuk merancang alat praktikum tersebut (Yennita et al., 2012; Sundari, 2008). Padahal kegiatan praktikum memberikan kesempatan bagi siswa menemukan dan membuktikan teori. Dalam pembelajaran IPA di sekolah khususnya pada materi fisika, banyak sekali pokok bahasan yang dapat menggunakan media pembelajaran dalam upaya membantu memperjelas pokok bahasan tersebut pada proses pembelajaran (Nurrita, 2018).

Media pembelajaran yang dimaksud adalah Kotak Instrumen Terpadu Ilmu Pengetahuan Alam (KIT IPA). Namun dalam kenyataannya ketidakcukupan atau keterbatas alat praktikum menjadi salah satu faktor penghambat guru dalam melaksanakan kegiatan praktikum di sekolah. Bila kondisi ini berlanjut, maka harapan kurikulum 2013 yang tidak hanya memprioritaskan kemampuan kognitif melainkan juga afektif dan psikomotor akan sulit terwujud (Budiaman, 2010). Pelaksanaan pembelajaran IPA Terpadu
(Integrated Science) hendaknya menumbuhkan scientific skills yaitu ketrampilan proses (science process skill), ketrampilan berpikir (thinking skill) yaitu berpikir kreatif dan berpikir kritis, serta bisa menumbuhkan sikap ilmiah (scientific attitude) (Diniya, 2019; Putra et al., 2015). Mata pelajaran matematika dan IPA akan lebih mudah dipahami apabila siswa menemukan langsung yakni melalui kegiatan paktikum. Djamarah dan Zain (2006) mengemukakan empat alasan pentingnya pembelajaran menggunakan praktikum, yaitu membangkitkan motivasi belajar, mengembangkan ketrampilan dasar, wahana belajar pendekatan ilmiah, dan menunjang materi pelajaran. Menurut Hayati et al. (2018), penerapan metode praktikum dapat meningkatkan keterampilan proses sains dalam mengobservasi, mengklasifikasi, memprediksi, mengukur, menyimpulkan dan mengkomunikasikan. Dalam hal ini pembelajaran praktikum memberi kesempatan bagi peserta didik untuk menemukan dan membuktikan teori.

Pentingnya melakukan praktikum di dukung dengan temuan penelitian yang dilakukan oleh Darmaji et al. (2019), yang mengungkapkan praktikum berbasis keterampilan proses sains pada materi efektif digunakan untuk meningkatkan keterampilan proses sains dalam mengamati, mengukur, memprediksi, mengidentifikasi variabel, merencanakan eksperimen, dan melakukan eksperimen. Dengan demikian salah satu alternatif solusi yang dapat diberikan untuk mengatasi kondisi keterbatasan alat dan bahan untuk praktikum adalah dengan memperkenalkan dan melatih guru dalam merancang kegiatan praktikum sederhana. Berdasarkan analisis dari situasi dan kondisi sekolah mitra serta beberapa permasalahan tersebut, maka dipandang perlu untuk dilakukan tindaklanjut terhadap guru MIPA di SMPN1 Nekamese terkait merancang praktikum MIPA sederhana. 


\section{METODOLOGI}

Metode kegiatan pengabdian ini adalah pelatihan tatap muka dalam bentuk penemuan terbimbing. Tahap kegiatan pertama adalah pemaparan materi oleh narasumber kemudian pelaksanaan praktikum sederhana serta evaluasi. Kegiatan ini dilaksanakan pada tanggal 10-12 Agustus 2020 di SMPN I Nekamese Kabupaten Kupang. Narasumber dalam kegiatan ini adalah Dr. Andam, S. M.Si., Kadek Ayu Astiti, M.Pd., dan Dr. Damianus D. Samo, M.Pd. Setelah diberi pelatihan, guru dibimbing untuk mengembangkan keterampilan melakukan percobaan sederhana pada konten matematika dan IPA. Pada konten matematika, percobaan sederhana dilakukan untuk membuktikan teorema secara induktid dan deduktif. Sedangkan pada konten IPA percobaan sederhana yang dilakukan berupa pembuktian aliran udara yang merambat pada bidang, sabun yang memisahkan ikatan antar molekul dll Tahapan yang akan dilakukan dalam melaksanakan program ini diantaranya:

1. Berkoordinasi dengan sekolah mitra dalam melaksanakan program ini.

2. Menetapkan narasumber dan instruktur dalam kegiatan program ini.

3. Melaksanakan kegiatan pelatihan dengan membahas topik di atas.

4. Melaksanakan pendampingan kepada guru-guru MIPA dalam merancang dan melaksanakan praktikum Matematika dan IPA sederhana untuk diterapkan dalam proses pembelajaran.

5. Evaluasi program dilakukan dengan melakukan analisis statistik Gain-score terhadap hasil pree test dan post test kemampuan guru-guru MIPA. Perhitungan perbedaan hasil pretest dan postest dilakukan dengan menggunakan rumus $\mathrm{N}$-gain.

\section{HASIL DAN PEMBAHASAN}

Kegiatan tim PKM bersama mitra adalah dilangsungkan mulai tanggal 10-12 Agustus 2020 dan bertempat di ruang laboratorium IPA SMPN 1 Nekamese. Kegiatan ini tidak hanya diikuti oleh guru-guru MIPA di sekolah mitra, namun juga ada beberapa guru MIPA dari sekolah lain di sekitar sekolah mitra yakni dari SMP N 2 Nekamese, SMP N 4 Nekamese, Kabupaten Kupang, NTT. Tahapan kegiatannya yakni pembukaan, pemberian materi, pendampingan kemudian evaluasi kegiatan. Kegiatan PKM ini dibuka secara resmi oleh pihak LP2M yang mana pada kesempatan ini ketua LP2M diwakili oleh kepala pusat IPTEK LP2M Undana.

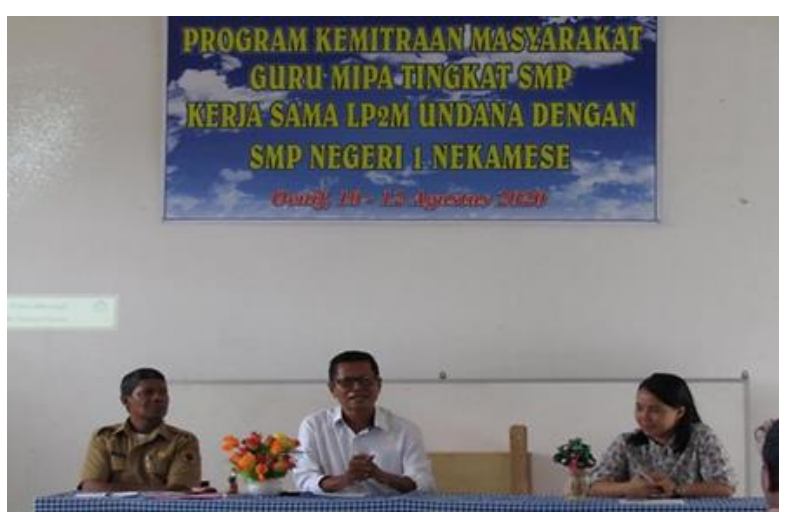

Gambar 1. Pembukaan Kegiatan PKM

Setelah acara pembukaan selesai, kemudian dilanjutkan dengan pemberian tes awal kepada peserta untuk mengetahui pengetahuan awal yang dimiliki peserta terkait dengan materi yang akan disampaikan.

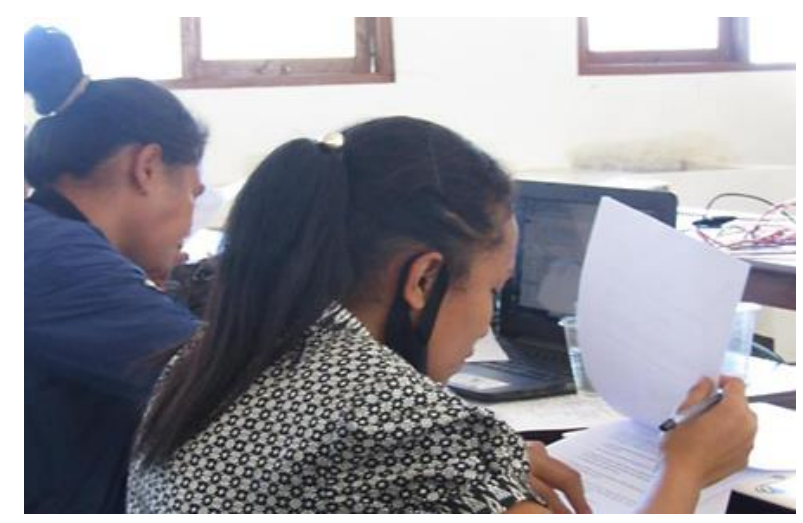

Gambar 2. Kegiatan Tes Awal 
Setelah pemberian pretest maka selanjutnya dilakukan pemberian materi oleh narasumber. Materi yang disampaikan oleh tiga narasumber yakni pembelajaran kontekstual IPA dan matematika serta konsep percobaan sederhana di Matematika dan IPA.

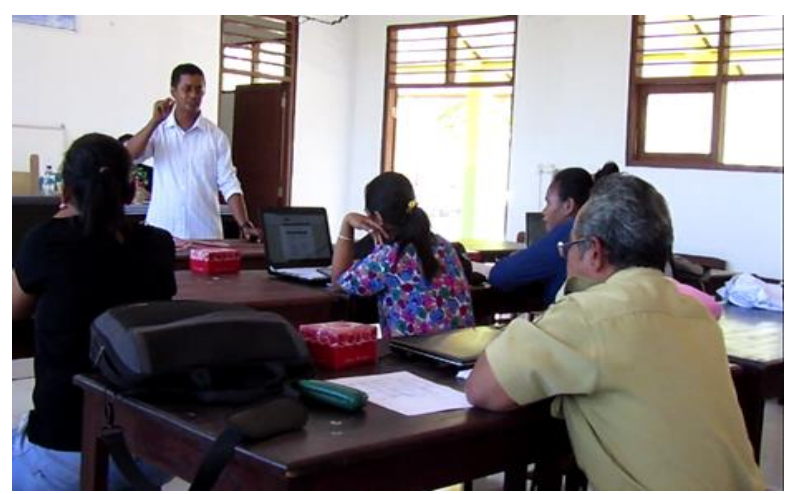

Gambar 3. Penyajian Materi oleh Narasumber

Tahapan selanjutnya adalah pelaksanan kegiatan percobaan sederhana oleh guru yang didampingi pemateri. Kegiatan percobaan sederhana IPA seperti meniup lilin yang menyala menggunakan corong.

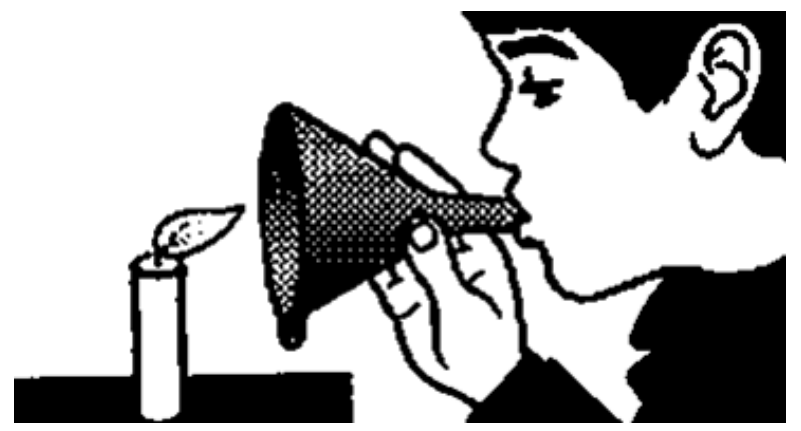

Gambar 4. Percobaan Meniup Api Menggunakan Corong

Api tidak akan padam, tapi api akan bergerak ke arah corong. Pada saat dmitiup tekanan udara di tengah corong akan berkurang sehingga udara luar akan mengalir ke dalam corong yang udaranya lebih renggang. Namun jika corongnya dibalikkan dan kita tiup pada lubang besar maka udara dalam leher corong memadat dan udara yang keluar langsung mematikan api. Gejala aneh ini dapat dijelaskan dengan hukum Bernoulli. Hukum ini mengatakan bahwa arus udara yang bergerak akan menciptakan tekanan yang lebih rendah disepanjang permukaan arus tersebut. Makin kencang gerakannya, makin rendah tekanan yang terjadi. Percobaan lainnya adalah mengetahui pengaruh detergen terhadap daya ikat antar molekul.

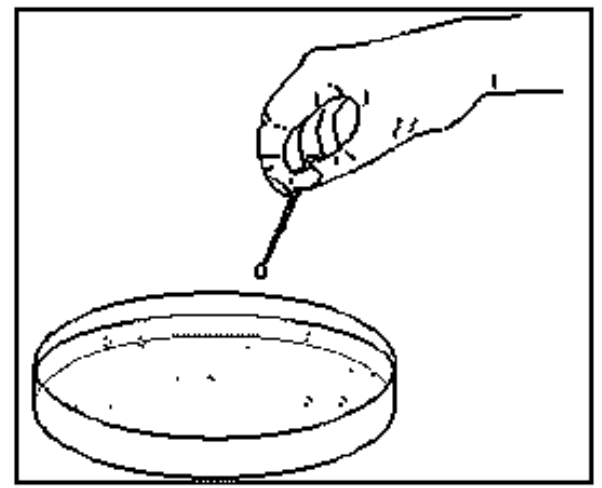

Gambar 5. Percobaan Pengaruh Deterjen Terhadap Daya Ikat Antar Molekul

Benang diletakan dalam bentuk melingkar diatas permukaan air dan tidak diikat, kemudian teteskanlah setetes sabun cair pada posisi ditengah lingkaran benang tersebut. Benang yang tadinya berbentuk lingkaran perlahan-lahan melebar sehingga ujung-ujungnya memisah. Hal ini karena pada awalnya, gaya tegang permukaan menahan posisi benang sehingga bisa berbentuk lingkaran. Tapi kemudian setelah ditetesi sabun cair, daerah disekitar tetesan sabun tersebut menjadi lemah ikatannya. Dan daerah permukaan diluar benang yang ikatan molekul airnya lebih kuat akan menarik benang sehingga bentuk benang menjadi melebar dan tidak lagi berbentuk lingkaran.

Beberapa percobaan tersebut memberikan pemahaman baru bagi guru dalam pembelajaran untuk mengaitkan konten teoritik dengan aplikasinya dlaam kehidupan. Di akhir pelatihan diberikan tes akhir untuk mengukur pemahaman guru terkait materi kegiatan pelatihan. Berdasarkan hasil pretest dan posttest, menunjukkan bahwa adanya peningkatan pemahaman guru terkait dengan praktikum MIPA sederhana dengan kategori Ngain tinggi. Dengan rata-rata pretest 65 dan posttest 95 $(\mathrm{N}$-gain $=0,86)$. 
Faktor pendukung dalam kegiatan ini adalah Kepala sekolah di sekolah mitra sangat mendukung kegiatan ini berlangsug dengan melihat berbagai manfaat yang diperoleh para guru MIPA di sekolah tersebut sehingga kegiatan ini dapat berjalan dengan cukup lancar, serta terdapat antusiasme guru untuk mengikuti kegiatan sehingga kegiatan ini berjalan sesuai rencana dengan dinamis dan interaktif. Sedangkan faktor penghambat adalah jarak tempat tinggal peserta yang cukup jauh dari tempat kegiatan dan kondisi jalan yang rusak membuat peserta memerlukan waktu yang lebih lama diperjalanan sehingga waktu untuk memulai kegiatan mengalami keterlambatan, dan adanya kegiatan sekolah yang bersamaan dengan kegiatan PKM ini di beberapa sekolah sekitar mitra membuat tidak semua guru MIPA di sekolah lain dapat turut mengikuti kegiatan ini.

\section{KESIMPULAN}

Program kemitraan masyarakat dalam bentuk pelatihan perencanaan praktikum sederhana matematika dan IPA bagi guru SMP di kecamatan Nekamese telah berjalan dengan baik dan memberikan dampak positif bagi guru. Guru memiliki pemahaman dan keterampilan guru dalam merancang dan melakukan percobaan sederhana sesuai bidang ilmunya. Pemahaman ini dibuktikan dengan hasil tes awal dan akhir yang meningkat dalam kategori tinggi.

\section{UCAPAN TERIMA KASIH}

Terima kasih berlimpah kepada Lembaga Penelitian dan Pengabdian Masyarakat Universitas Nusa Cendana yang telah berkenan mendukung pembiayaan dan pelaksanaan kegiatan PKM ini serta kepala sekolah SMPN1 Nekamese yang dengan terbuka menerima tim PKM untuk melaksanakan kegiatan di SMPN 1 Nekamese serta semua peserta yang terlibat dalam kegiatan ini.

\section{REFERENSI}

Budiaman. 2010. Analisis Faktor-Faktor Kesulitan Penerapan E-Learning Dalam Pembelajaran IPS. Jurnal Sujarah Lontar. 7(2):50-60. https://doi.org/10.21009/LONTAR.072.05

Darmaji, Kurniawan, D.A., Suryani, A. 2019. Effectiveness of Basic Physics II Practicum Guidelines Based on Science Process Skills. JIPF (Jurnal Ilmu Pendidikan Fisika). 4(1):1-7. https://doi.org/10.26737/jipf.v4i1.693

Diniya, D. 2019. Pembelajaran IPA Terpadu Tipe Integrated melalui Model Inkuiri Terbimbing Tingkat Sekolah Menengah Pertama. Journal of Natural Science and Integration. 2(2):143-152. http://dx.doi.org/10.24014/jnsi.v2i2.7580

Djamarah, S.B., Zain, A. 2006. Strategi Belajar Mengajar. Jakarta: Rineka Cipta.

Hayati, D.P., Bintari, S.H., Sukaesih, S. 2018. Implementation of the Practicum Methods with Guided-Discovery Model to the Student Skill of Science Process. Journal of Biology Education. 7(1):118-126. https://doi.org/10.15294/jbe.v7i1.23005

Nurrita, T. 2018. Pengembangan Media Pembelajaran Untuk Meningkatkan Hasil Belajar Siswa. Misykat: Jurnal Ilmu-ilmu Al-Qur'an, Hadist, Syariah dan Tarbiyah. 3(1):171-187. http://dx.doi.org/10.33511/misykat.v3n1.17 1

Putra, N.A.R., Abdurrahman, Suana, W. 2015. Pengaruh Keterampilan Proses Sains Dan Sikap Ilmiah Terhadap Pemahaman Konsep IPA Siswa SMP. Jurnal Pembelajaran Fisika. 3(4):33-42.

Rahman, D., Adlim, Mustanir. 2015. Analisis Kendala Dan Alternatif Solusi Terhadap Pelaksanaan Praktikum Kimia Pada Slta Negeri Kabupaten Aceh Besar. Jurnal Pendidikan Sains Indonesia (Indonesian Journal of Science Education). 3(2):113.

Samura, A.O. 2015. Penggunaan Media Dalam Pembelajaran Matematika Dan Manfaatnya. Delta-Pi: Jurnal Matematika dan Pendidikan Matematika. 4(1):69-79. http://dx.doi.org/10.33387/dpi.v4i1.145

Sulthon. 2016. Pembelajaran IPA yang Efektif dan Menyenangkan bagi Siswa MI. Elementary: 
Islamic Teacher Journal. 4(1):38-54. http://dx.doi.org/10.21043/elementary.v4i1. 1969

Sumartini, T.S. 2016. Peningkatan Kemampuan Pemecahan Masalah Matematis Siswa melalui Pembelajaran Berbasis Masalah. Mosharafa: Jurnal Pendidikan Matematika. 5(2):148-158. https://doi.org/10.31980/mosharafa.v5i2.27 0

Sundari, R. 2008. Evaluasi Pemanfaatan Laboratorium Dalam Pembelajaran Biologi Di Madrasah Aliyah Negeri Sekabupaten Sleman. Jurnal Penelitian dan Evaluasi Pendidikan. 12(2):196-212. https://doi.org/10.21831/pep.v12i2.1427

Yennita, Sukmawati, M., Zulirfan. 2012. Hambatan Pelaksanaan Praktikum IPA Fisika Yang Dihadapi Guru SMP Negeri Di Kota Pekanbaru. Jurnal Pendidikan. 3(1):1-11. http://dx.doi.org/10.31258/jp.3.1.\%25p 